\title{
Factors affecting the quality of life in hemifacial spasm patients
}

\section{Czynniki determinujące jakość życia chorych na połowiczy kurcz twarzy}

\author{
Monika Rudzińska', Magdalena Wójik', Michalina Malec', Natalia Grabska', Michał Szubiga', Marcin Hartel', Andrzej Szczudlik' \\ 1 Katedra i Klinika Neurologii, Collegium Medicum Uniwersytetu Jagiellońskiego, Kraków \\ 2Medyczne Centra Diagnostyczne Voxel, Zabrze
}

Neurologia i Neurochirurgia Polska 2012; 46, 2: 121-129

DOI: 10.5114/ninp.2012.28254

\begin{abstract}
Background and purpose: Hemifacial spasm (HFS), a movement disorder manifested by unilateral spasms of the muscles innervated by the facial nerve, interferes with social life in about $90 \%$ of patients, causing social isolation and depression and having a significant impact on the quality of life. The aim of the study was to assess factors affecting the quality of life in patients with HFS in respect of influence of the severity of depression symptoms and botulinum toxin type A (BTX-A) therapy.

Material and methods: Eighty-five out of 129 patients included in the HFS database of the Movement Disorders Outpatient Clinic, Department of Neurology, University Hospital, Cracow who fulfilled the inclusion criteria and had no exclusion criteria (suffering from concomitant movement disorders, other severe chronic diseases or cognitive impairment) were studied. Demographic and clinical data (age at onset, disease duration and accompanying symptoms) were collected. Severity of HFS was assessed by the five-point clinical scale and seven-point Clinical Global Impression scale. Quality of life was assessed with the HFS-36 questionnaire and severity of depressive symptoms was evaluated with the Beck Depression Inventory. HFS-36 was performed twice, before BTX-A injection and two weeks later.
\end{abstract}

Results: The mean global score of HFS-36 was $47 \pm 31$ (maximum: 140 pts). Decreased HFS-36 score resulted from divergent deterioration in all subscales included in the questionnaire. Independent risk factors of deterioration in HFS-36

\section{Streszczenie}

Wstęp i cel pracy: Połowiczy kurcz twarzy (hemifacial spasm - HFS), charakteryzujący się przewlekłym występowaniem jednostronnych skurczów mięśni unerwianych przez nerw twarzowy, zaburza funkcjonowanie społeczne prawie $90 \%$ chorych, powodując ich społeczną izolację, a nawet depresję, i w konsekwencji pogarsza jakość życia. Celem badania była ocena czynników determinujących jakość życia chorych z HFS z uwzględnieniem wpływu nasilenia objawów depresyjnych i leczenia toksyną botulinową (BTX-A).

Materiał i metody: Badaniem objęto 85 ze 129 chorych leczonych w Poradni Kliniki Neurologii Szpitala Uniwersyteckiego w Krakowie, którzy spełniali kryteria włączenia do badania i u których nie stwierdzono cech wyłączających z badania (współistniejące choroby ruchu i inne przewlekłe choroby o dużym nasileniu objawów oraz zaburzenia funkcji poznawczych). U wszystkich chorych rejestrowano dane demograficzne i kliniczne (wiek zachorowania, czas trwania, objawy towarzyszące). Nasilenie objawów HFS oceniano za pomocą 7-stopniowej skali Clinical Global Impression i 5-stopniowej skali klinicznej; badanie jakości życia przeprowadzono z użyciem kwestionariusza HFS-36, a nasilenie objawów depresyjnych oceniano za pomocą inwentarza depresji Becka. Kwestionariusz HFS-36 wypełniano dwukrotnie, bezpośrednio przed podaniem BTX-A oraz 2 tygodnie później.

Wyniki: Średni globalny wynik oceny jakości życia w kwestionariuszu HFS-36 wyniósł $47 \pm 31$ pkt (na 140 możliwych). Obniżenie jakości życia dotyczyło w różnym stopniu

Correspondence address: dr n. med. Monika Rudzińska, Katedra i Klinika Neurologii, Uniwersytet Jagielloński Collegium Medicum, ul. Botaniczna 3, 31-503 Kraków, tel. +48 1242486 00; faks +48 1242486 26, e-mail: rudzinsk@neuro.cm-uj.krakow.pl

Received: 22.07.2011; accepted: 18.01.2012 
were increased severity of HFS and depressive symptoms as well as accompanying trismus. The HFS-36 score depended on the number and type of accompanying symptoms as well. Botulinum toxin type A therapy led to a significant improvement of HFS-36, particularly high in patients with multiple ( $>4$ ) HFS-related symptoms.

Conclusions: The HFS-36 score depends mostly on severity of HFS, depressive symptoms and occurrence of accompanying trismus. It improves after BTX-A treatment.

Key words: hemifacial spasm, quality of life, HFS-36.

\section{Introduction}

Hemifacial spasm (HFS) is a nervous system disorder manifesting with involuntary clonic or tonic contractions of the muscles innervated by the facial nerve and affecting one half of the face. Chronic HFS symptoms interfere with social functioning in almost $90 \%$ of patients, leading to the loss of self-confidence, social isolation, and even depression that markedly impair the quality of life in those patients [1]. Only a few papers have been published so far on the quality of life in HFS patients, using various questionnaires and showing a significant decrease of quality of life in HFS patients when compared with control groups $[2,3]$.

The results of the questionnaire-based quality of life assessment depend on multiple different factors. Tan and colleagues found that better educated patients who were better informed about the causes, course and management of HFS had better quality of life improvement after botulinum toxin type A (BTX-A) injections than patients having more limited knowledge on that disease [4]. Studies on factors that determine the quality of life in HFS are scarce, however. Despite the known impact of depression and anxiety on HFS symptoms [5-7], no studies have been performed so far to evaluate the influence of those emotions on the quality of life assessed with questionnaires dedicated to HFS patients, such as HFS-36. The results of studies published to date and related to other movement disorders show that depression is the most important factor determining the quality of life in Parkinson disease [8-15], dystonia [16-19], essential tremor [21], progressive supranuclear palsy [22], multisystem atrophy [23], Gilles de la Tourette syndrome [24], and orthostatic tremor [25]. Other factors that affect the quality of life in those disorders include anxiety $[11,20]$, severity of symptoms $[10,11,15,18,21,23,24]$, insom- wszystkich podskal kwestionariusza. Niezależnym czynnikiem ryzyka gorszej jakości życia było większe nasilenie objawów HFS, większe nasilenie objawów depresyjnych oraz współwystępujący szczękościsk. Wynik w HFS-36 zależał także od liczby oraz rodzaju występujących objawów towarzyszących. Leczenie BTX-A poprawiało jakość życia, szczególnie u chorych z dużą liczbą objawów towarzyszących.

Wnioski: Jakość życia w HFS zależy od nasilenia objawów HFS, nasilenia objawów depresyjnych oraz występowania szczękościsku i poprawia się po leczeniu BTX-A.

Słowa kluczowe: połowiczy kurcz twarzy, jakość życia, HFS-36.

nia [10], dementia [15], abnormal executive functions [21], and limited social support $[15,17]$.

The aim of the study was to identify factors having a major impact on the quality of life in HFS patients in respect of depressive symptoms severity and effective treatment with BTX-A.

\section{Material and methods}

This study included patients of the Movement Disorders Outpatient Clinic of the Department of Neurology, University Hospital of Cracow, who were treated between 2004 and 2010. Participation in this study was offered to each patient who attended the clinic and had HFS diagnosed by a specialist with expertise in movement disorder (M.R.) according to the typical clinical picture. Patients were included if they provided informed consent to participate and had no exclusion criteria, which consisted of concomitant movement disorders, heart failure, pulmonary, renal or hepatic insufficiency, or malignancy. Patients were also excluded if they had cognitive impairment and could not therefore reliably answer the questions included in the quality of life questionnaire and in the Beck Depression Inventory (BDI).

Demographic and clinical data of those patients were collected prospectively in a dedicated electronic database. The collected data included age at onset of the disease, duration and course of the disease, the affected side, accompanying symptoms (visual disturbances, pain, discomfort, dysarthria, sialorrhoea, paraesthesias, bruxism, trismus, photophobia, lacrimation, conjunctival irritation, hearing disturbances), factors aggravating or alleviating the facial muscle contractions, concomitant disorders, family history and treatment used. The severity of HFS symptoms was assessed in each patient before the BTX-A injection with the 7-point Clinical Global 
Impression (CGI) scale and with the 5-point scale proposed by Tan and Jankovic [26]. Each patient had magnetic resonance imaging (MRI) of the head performed with the detailed assessment of cerebellopontine angles to discern between idiopathic and symptomatic HFS.

The quality of life was assessed in all patients with the HFS-36 questionnaire [27]; severity of depressive symptoms was evaluated with BDI [28]. The HFS-36 questionnaire used in the present study contains subscales related to eight functional domains, i.e. mobility (5 questions), activity of daily living (5 questions), emotional well-being (7 questions), stigma related to the disease (5 questions), social support (3 questions), cognition (3 questions), communication (3 questions), and complaints of bodily discomfort (5 questions) associated with symptoms accompanying HFS, such as hearing problems, sleep disorders, facial paraesthesias, eye irritation, lacrimation, photophobia and sialorrhoea. Each question in the HFS-36 questionnaire is scored from 0 to 4 points; maximum score is 140 points.

The severity of depressive symptoms was evaluated with BDI, which contains 21 questions, each scored from 0 to 3 points. The BDI score was interpreted according to the following scores: $0-9$ points - normal; 10-19 points - mild depressive symptoms; 20-30 points - moderate depressive symptoms; $>30$ points - severe depressive symptoms [29]. Depression was diagnosed according to the opinion of the consulting psychiatrist or due to ongoing treatment with antidepressant(s) prescribed previously by the psychiatrist after earlier diagnosis of depression.

The quality of life and severity of depressive symptoms were assessed always after the patient's qualification for the next BTX-A injection, at least 12 weeks after the previous injection, i.e. after the resolution of the therapeutic effect of the previous BTX-A dose. Patients were evaluated just before the BTX-A (Botox ${ }^{\circledR}$ ) injection in a total dose of $25 \mathrm{U}$ to the five standard locations within the face and were scheduled for the follow-up visit after two weeks for the repeated assessment of quality of life.

\section{Statistical analysis}

Numerical variables were characterised with mean \pm standard deviation (SD). All analysed numerical variables had normal distribution; hence Student's $t$-test was used to assess the differences in variances. The statistical significance between categorical variables was assessed with the $\chi^{2}$ test. Spearman's rank correlation coefficient was used to assess the reciprocal associations between numerical variables. Univariate and multivariate logistic regression models were used to assess risk factors. A $p$-value $<0.05$ was considered significant for all analyses. All statistical analyses were conducted using commercial statistical software (STATISTICA for Windows, v.6.0, StatSoft Inc., version 9.2, Poland) licensed to Jagiellonian University.

\section{Results}

This study included 85 out of the 129 patients diagnosed with HFS and registered in the database (Table 1). Twenty-six patients did not consent to participate, and 18 other patients had various exclusion criteria. The studied group did not differ from all registered patients regarding age (mean age of studied patients and all registered patients: $60.8 \pm 10.3$ vs. $61.6 \pm 11.4$,

Table 1. Characteristics of the studied patients

\begin{tabular}{|c|c|}
\hline Number of patients & 85 \\
\hline Sex (women) & $58(69 \%)$ \\
\hline Age $[$ years], mean $\pm \mathrm{SD}$ & $60.8 \pm 10.3$ \\
\hline Age at disease onset [years], mean $\pm \mathrm{SD}$ & $53.2 \pm 12.6$ \\
\hline Disease duration [years], mean $\pm \mathrm{SD}$ & $7.1 \pm 5.1$ \\
\hline \multicolumn{2}{|l|}{ Severity of hemifacial spasm: } \\
\hline $\begin{array}{l}\text { Clinical Global Impression Scale score, } \\
\text { mean } \pm \mathrm{SD}\end{array}$ & $5.3 \pm 1.1$ \\
\hline Five-point scale score, mean $\pm \mathrm{SD}$ & $2.8 \pm 0.8$ \\
\hline \multicolumn{2}{|c|}{ Number (\%) of patients with particular severity grade: } \\
\hline grade 0 & 0 \\
\hline grade 1 & $6(7.0 \%)$ \\
\hline grade 2 & $19(22.3 \%)$ \\
\hline grade 3 & $47(55.3 \%)$ \\
\hline grade 4 & $13(15.3 \%)$ \\
\hline $\begin{array}{l}\text { Number (\%) of patients with depression } \\
\text { diagnosed with DSM-IV }\end{array}$ & $17(20 \%)$ \\
\hline \multicolumn{2}{|l|}{$\begin{array}{l}\text { Severity of depressive symptoms according } \\
\text { to Beck Depression Inventory (score): }\end{array}$} \\
\hline $0-9$ (normal) & $43(50.6 \%)$ \\
\hline 10-19 (mild depressive symptoms) & $20(23.5 \%)$ \\
\hline 20-30 (moderate depressive symptoms) & $11(12.9 \%)$ \\
\hline$>30$ (severe depressive symptoms) & $11(12.9 \%)$ \\
\hline
\end{tabular}

$S D-$ standard deviation 
respectively), sex (women: 69\% vs. 68\%, respectively), mean age at onset of symptoms (53.2 \pm 12.6 vs. $52.5 \pm 12.2$ years, respectively) and mean duration of disease ( $7.1 \pm 5.1$ vs. $9.1 \pm 10.3$ years, respectively).

Mean score of the global quality of life assessment, i.e. the sum of all subscores obtained in HFS-36, was $47.0 \pm 30.9$ (maximum: 140 pts). Mean scores in particular quality of life domains assessed in subscales of that questionnaire were as follows: mobility $5.45 \pm 4.9$ (maximum 20 pts); activity of daily living $5.7 \pm 4.4$ (maximum 16 pts); emotional well-being $9.1 \pm 7.3$ (maximum 28 pts); stigma $9.2 \pm 5.9$ (maximum 20 pts); social support $2.6 \pm 3.0$ (maximum 12 pts); cognition $4.7 \pm 3.6$ (maximum 12 pts); bodily discomfort $7.9 \pm 4.9$ (maximum 16 pts); communication $2.2 \pm 2.8$ (maximum 16 pts).

The severity of symptoms in HFS-36 correlated with the severity of symptoms in the CGI scale $(r=0.28$, $p=0.009)$ and in the 5-point scale assessing the severity of $\operatorname{HFS}(r=0.37, p=0.002)$, as well as with the number of symptoms accompanying $\operatorname{HFS}(r=0.37$, $p=0.001)$. The strongest correlation was noted between symptom severity in HFS-36 and severity of depressive symptoms in BDI $(r=0.56, p=0.0000)$ (Fig. 1); there was no correlation, however, between HFS-36 score and age or duration of the disease or age at onset of symptoms (Table 2). Women had worse quality of life than men in the subscale assessing the stigma $\left(\chi^{2}=2.3\right.$, $p=0.04)$.

The BDI score did not correlate with age, sex, age at onset of symptoms or with duration of the disease; it correlated, however, with scales used to assess the severity of HFS: CGI $(r=0.32, p=0.003)$ and fivepoint scale $(r=0.35, p=0.001)$.

Facial pain or discomfort (reported by $20 \%$ of patients) and trismus (15.3\%) were the symptoms accom-

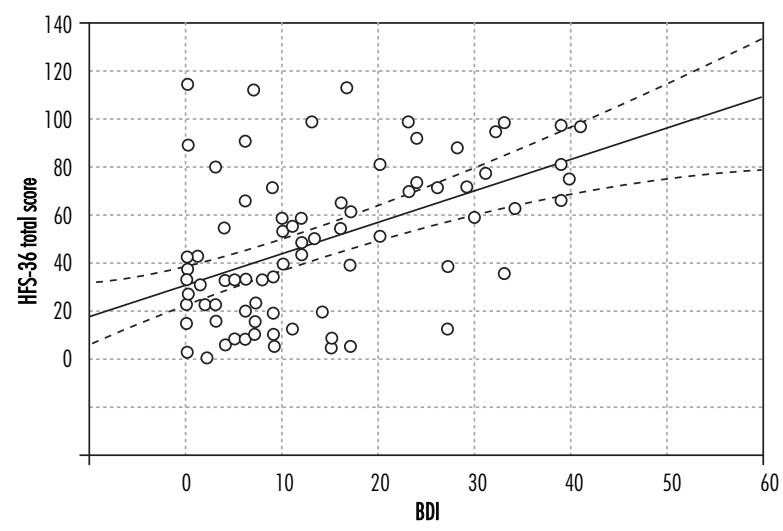

Fig. 1. Correlation between the severity of depressive symptoms according to the Beck Depression Inventory (BDI) and the quality of life assessed by HFS-36 panying HFS with the greatest impact on the quality of life assessed in many HFS-36 subscales. Some accompanying symptoms, such as dysarthria (reported by $22.3 \%$ of patients), sialorrhoea $(17.6 \%)$, bruxism $(5.9 \%)$, lacrimation $(34.1 \%)$, or eye irritation $(27 \%)$, had no significant impact on quality of life. Some other symptoms, such as visual disturbances, paraesthesias, photophobia, hypoacusis and ear clicks, significantly worsen quality of life in single subscales, e.g. bodily discomfort or communication (Table 3 ).

Multivariate logistic regression revealed that the independent risk factors of worse quality of life in patients with HFS included greater severity of disease symptoms in the five-point scale (OR: 2.37; 95\% CI: $1.14-4.9, p=0.02)$, greater severity of depressive symptoms (OR: $1.10 ; 95 \% \mathrm{CI}: 1.04-1.17, p=0.001$ ) and the presence of trismus (OR: 6.44, 95\% CI: 1.21-34.31; $p=0.03)$. In the parallel model, including the CGI scale instead of the five-point scale, greater severity of HFS symptoms was shown to be an independent risk factor of worse quality of life in HFS patients as well (OR: 1.73 ; 95\% CI: 1.24-2.41, $p=0.001$ ). The fivepoint scale and CGI scale were alternately included in the multivariate logistic regression model because they measure the same feature, i.e. severity of HFS symptoms, and their close correlation could disturb the appropriate modelling of independent risk factors.

Treatment with BTX-A markedly improved the quality of life scores in studied patients with HFS; mean HFS-36 score decreased from $47.0 \pm 30.9$ before treatment to $28.6 \pm 23.7$ after treatment $(t=4.3, p=$ $0.00003)$. Significant improvement was noted in all subscales except for the social support subscale (Table 4, Fig. 2).

The impact of treatment with BTX-A on quality of life was also assessed in relationship to the number of symptoms accompanying HFS. Patients were divided into two groups: (a) those with less than 4 accompanying symptoms, and (b) those with $\geq 4$ accompanying symptoms. Sixty-two (72.9\%) patients reported less than 4 accompanying symptoms and $23(27.1 \%)$ had at least 4 accompanying symptoms. Patients with a smaller number of accompanying symptoms did not differ from those with a greater number of accompanying symptoms regarding age $(59.7 \pm 12.4$ vs. $59.4 \pm 8.1$ years, respectively), age at onset of symptoms ( $52.7 \pm 13.1$ vs. 53.1 \pm 9.2 years, respectively) or duration of the disease $(6.8 \pm 4.9$ vs. $7.3 \pm 6.0$ years, respectively). Patients with a greater number of accompanying signs had greater severity of HFS motor symptoms in the CGI 
Table 2. The relation of quality of life assessments (HFS-36 total score and subscale scores) with the clinical features of the disease

\begin{tabular}{|c|c|c|c|c|c|c|c|c|c|}
\hline \multirow{2}{*}{$\begin{array}{l}\text { Clinical } \\
\text { features } \\
\text { of HFS }\end{array}$} & \multicolumn{8}{|c|}{ HFS-36 subscale scores } & \multirow{2}{*}{$\begin{array}{c}\text { HFS-36 } \\
\text { total } \\
\text { score }\end{array}$} \\
\hline & Mobility & $\begin{array}{l}\text { Activity } \\
\text { of daily } \\
\text { living }\end{array}$ & $\begin{array}{l}\text { Emotional } \\
\text { well-being }\end{array}$ & $\begin{array}{l}\text { Stigma } \\
\text { related } \\
\text { to the } \\
\text { disease }\end{array}$ & $\begin{array}{l}\text { Social } \\
\text { support }\end{array}$ & Cognition & $\begin{array}{c}\text { Bodily } \\
\text { discomfort }\end{array}$ & $\begin{array}{l}\text { Communi- } \\
\text { cation }\end{array}$ & \\
\hline Age* & NS & NS & NS & $\begin{array}{c}r=-0.23 \\
p=0.03\end{array}$ & NS & NS & NS & NS & NS \\
\hline Sex** & NS & NS & $\mathrm{NS} t=$ & $\begin{aligned} & \text { women: } \\
= & 2.3 ; p=0.02 \\
& \text { men: NS }\end{aligned}$ & $02 \stackrel{\text { NS }}{ }$ & NS & NS & NS & NS \\
\hline CGI score* & NS & $\begin{array}{c}r=0.26 \\
p=0.016\end{array}$ & $\begin{array}{l}r=0.25 \\
p=0.02\end{array}$ & NS & $\begin{array}{l}r=0.25 \\
p=0.02\end{array}$ & $\begin{array}{l}r=0.27 \\
p=0.01\end{array}$ & NS & NS & $\begin{array}{c}r=0.28 \\
p=0.009\end{array}$ \\
\hline $\begin{array}{l}\text { Five-point scale } \\
\text { score (severity of } \\
\text { HFS symptoms)* }\end{array}$ & $\begin{array}{l}r=0.25 \\
p=0.02\end{array}$ & $\begin{array}{c}r=0.34 \\
p=0.001\end{array}$ & $\begin{array}{c}r=0.32 \\
p=0.003\end{array}$ & $\begin{array}{c}r=0.29 \\
p=0.007\end{array}$ & $\begin{array}{c}r=0.30 \\
p=0.005\end{array}$ & $\begin{array}{c}r=0.37 \\
p=0.001\end{array}$ & $\begin{array}{c}r=0.33 \\
p=0.002\end{array}$ & $\begin{array}{c}r=0.31 \\
p=0.003\end{array}$ & $\begin{array}{c}r=0.37 \\
p=0.0000\end{array}$ \\
\hline Side** & NS & NS & NS & NS & NS & NS & NS & NS & NS \\
\hline $\begin{array}{l}\text { Number of } \\
\text { accompanying signs }\end{array}$ & NS & $\begin{array}{c}r=0.30 \\
p=0.006\end{array}$ & $\begin{array}{c}r=0.32 \\
p=0.003\end{array}$ & $\begin{array}{l}r=0.21 \\
p=0.05\end{array}$ & $\begin{array}{c}r=0.29 \\
p=0.008\end{array}$ & $\begin{array}{c}r=0.36 \\
p=0.001\end{array}$ & $\begin{array}{c}r=-0.45 \\
p=0.00\end{array}$ & $\begin{array}{l}r=0.35 \\
p=0.001\end{array}$ & $\begin{array}{l}r=-0.37 \\
p=0.001\end{array}$ \\
\hline $\begin{array}{l}\text { Duration } \\
\text { of the disease* }\end{array}$ & NS & NS & NS & NS & NS & NS & NS & NS & NS \\
\hline $\begin{array}{l}\text { Beck Depression } \\
\text { Inventory score }\end{array}$ & $\begin{array}{l}r=0.33 \\
p=0.002\end{array}$ & $\begin{array}{c}r=0.38 \\
p=0.0000\end{array}$ & $\begin{array}{c}r=0.56 \\
p=0.0000\end{array}$ & $\begin{array}{c}r=0.47 \\
p=0.0000 p\end{array}$ & $\begin{array}{c}r=0.47 \\
p=0.0000\end{array}$ & $\begin{array}{c}r=0.52 \\
p=0.0000\end{array}$ & $\begin{array}{c}r=0.53 \\
p=0.0000\end{array}$ & $\begin{array}{c}r=0.41 \\
p=0.0000\end{array}$ & $\begin{array}{c}r=0.56 \\
p=0.0000\end{array}$ \\
\hline $\begin{array}{l}\text { Age at onset } \\
\text { of the disease* }\end{array}$ & NS & NS & NS & NS & NS & NS & NS & NS & NS \\
\hline
\end{tabular}

HFS - hemifacial spasm; CGI - Clinical Global Impression; NS - non-significant

* Statistical analysis was performed using Spearman's rank correlation coefficient

** Statistical analysis was performed using Student's t-test

scale $(5.6 \pm 0.9$ vs. $4.7 \pm 1.3$ pts; $p=0.005)$ and in the five-point scale $(3.0 \pm 0.5$ vs. $2.5 \pm 1.0$ pts, $p=0.01)$; they also had greater severity of depressive symptoms in the BDI $(20.3 \pm 11.4$ vs. $10.9 \pm 9.3$ pts, $p=0.003)$. Patients with a greater number of accompanying symptoms achieved significantly greater improvement in all HFS-36 subscales after the treatment with BTX-A than the patients with a small number of HFS accompanying symptoms (Table 4).

\section{Discussion}

This study revealed that the mean score of the global assessment of the quality of life with the HFS-36 questionnaire was $47.0 \pm 30.9$ pts out of the maximum score of 140 points. This finding suggests the diseaserelated worsening of the quality of life, but its direct interpretation, e.g. regarding the degree of that worsening, is impossible. The available literature does not contain any studies using HFS-36 in a control group except for studies performed for validation purposes; this paucity results from the specificity of the questionnaire, which is directed towards the symptoms typical for the disease; the expected result of the study in a control group would therefore be close to zero.

Both our study and the study of Huang et al. [27] showed that the following subscales had the greatest impact on the global score of quality of life scale: stigma (mean score in our own study and in the mentioned study: 9.9 and 31.7 pts, respectively), bodily discomfort (8.0 and 16.9 pts) and emotional well-being (9.5 and 15.7 pts). Communication (2.6 and 2.8 pts) and social support (2.9 and 1.1 pts) had the smallest impact on quality of life. Despite the similar relationships regarding the impact on the global score, there is a marked difference in terms of mean scores between our own study and the paper of Huang and colleagues [27]. It may result from cultural differences. Huang et al. [27] per- 
Table 3. The relationship between quality of life and the presence of accompanying signs, as assessed before botulinum toxin injection

\begin{tabular}{|c|c|c|c|c|c|c|c|c|c|}
\hline \multirow{2}{*}{$\begin{array}{l}\text { Accompanying } \\
\text { signs }\end{array}$} & \multicolumn{6}{|c|}{ HFS-36 } & \multicolumn{3}{|c|}{ Total } \\
\hline & Mobility & $\begin{array}{l}\text { Activity } \\
\text { of daily } \\
\text { living }\end{array}$ & $\begin{array}{l}\text { Emotional } \\
\text { well-being }\end{array}$ & Stigma & $\begin{array}{l}\text { Social } \\
\text { support }\end{array}$ & Cognition & $\begin{array}{c}\text { Bodily } \\
\text { discomfort }\end{array}$ & $\begin{array}{l}\text { Communi- } \\
\text { cation }\end{array}$ & \\
\hline $\begin{array}{l}\text { Visual disturbances } \\
n=44(51.8 \%)\end{array}$ & NS & NS & NS & NS & NS & NS & $p=0.004$ & $p=0.007$ & NS \\
\hline $\begin{array}{l}\text { Pain and } \\
\text { discomfort } \\
n=17(20 \%)\end{array}$ & $p=0.01$ & $p=0.04$ & $p=0.02$ & NS & NS & $p=0.01$ & NS & NS & $p=0.04$ \\
\hline $\begin{array}{l}\text { Dysarthria } \\
n=19(22.3 \%)\end{array}$ & NS & NS & NS & NS & NS & NS & NS & NS & NS \\
\hline $\begin{array}{l}\text { Sialorrhoea } \\
n=15(17.6 \%)\end{array}$ & NS & NS & NS & NS & NS & NS & NS & NS & NS \\
\hline $\begin{array}{l}\text { Paraesthesias } \\
n=21(24.7 \%)\end{array}$ & NS & NS & NS & NS & NS & NS & $p=0.002$ & NS & NS \\
\hline $\begin{array}{l}\text { Bruxism } \\
n=5(5.9 \%)\end{array}$ & NS & NS & NS & NS & NS & NS & NS & NS & NS \\
\hline $\begin{array}{l}\text { Trismus } \\
n=13(15.3 \%)\end{array}$ & $p=0.008$ & NS & $p=0.04$ & $p=0.003$ & NS & $p=0.01$ & $p=0.006$ & $p=0.006$ & $p=0.004$ \\
\hline $\begin{array}{l}\text { Photophobia } \\
n=21(24.7 \%)\end{array}$ & NS & NS & NS & NS & NS & NS & $p=0.0006$ & NS & NS \\
\hline $\begin{array}{l}\text { Lacrimation } \\
n=29(34.1 \%)\end{array}$ & NS & NS & NS & NS & NS & NS & NS & NS & NS \\
\hline $\begin{array}{l}\text { Conjunctival } \\
\text { irritation } \\
n=32(37.6 \%)\end{array}$ & NS & NS & NS & NS & NS & NS & NS & NS & NS \\
\hline $\begin{array}{l}\text { Hypoacusis } \\
n=23(27 \%)\end{array}$ & NS & NS & NS & NS & NS & $p=0.02$ & $p=0.001$ & $p=0.01$ & NS \\
\hline $\begin{array}{l}\text { Ear clicks } \\
n=22(25.9 \%)\end{array}$ & NS & NS & NS & NS & NS & NS & $p=0.03$ & $p=0.02$ & NS \\
\hline
\end{tabular}

NS-non-significant

formed their study and validated the HFS-36 questionnaire in a population of Taiwan that may more profoundly experience the stigma related to the disease and may be less tolerant of the worse well-being in relation to the disease and visible facial defect.

We did not find an association between the global assessment of the quality of life and sex, which is concordant with another study [27]. Significant differences between sexes were noted, however, in some subscales. Women had markedly higher scores in the stigma domain, which was also noted by the above-mentioned authors. The difference between sexes regarding the emotional well-being and cognition subscales, found by Huang et al. [27], was not found in our patients. Lack of a relationship between quality of life and sex was also noted in many other movement disorders, although the results in some of those disorders, e.g. in focal dystonia, are controversial. For example, Müller et al. [16] found that the quality of life was significantly worse in women than in men with blepharospasm, while no sex-related difference was found in synchronously studied patients with torticollis. In a Polish study by Sławek et al. [17], the quality of life among women was significantly worse than among men.

We observed a correlation between the quality of life score according to HFS-36, both globally and in particular subscales, and the severity of HFS symptoms according to the five-point HFS scale and CGI scale. Similar results were obtained in several previous studies using different versions of the questionnaire (HFS-30, 
Table 4. The impact of treatment with botulinum toxin (BTX-A) on the quality of life in relation to the number of signs accompanying hemifacial spasm (HFS)

\begin{tabular}{|c|c|c|c|c|c|c|c|c|c|}
\hline \multirow[t]{2}{*}{ HFS-36 } & \multicolumn{3}{|c|}{ All HFS patients $(n=85)$} & \multicolumn{3}{|c|}{$\begin{array}{c}\text { HFS patients with } \\
<4 \text { accompanying signs }\end{array}$} & \multicolumn{3}{|c|}{$\begin{array}{c}\text { HFS patients with } \\
\geq 4 \text { accompanying signs }\end{array}$} \\
\hline & $\begin{array}{l}\text { Mean } \\
\text { before } \\
\text { BTX-A }\end{array}$ & $\begin{array}{c}\text { Mean } \\
\text { after } \\
\text { BTX-A }\end{array}$ & p-value & $\begin{array}{l}\text { Mean } \\
\text { before } \\
\text { BTX-A }\end{array}$ & $\begin{array}{c}\text { Mean } \\
\text { after } \\
\text { BTX-A }\end{array}$ & $p$-value & $\begin{array}{c}\text { Mean } \\
\text { before } \\
\text { BTX-A }\end{array}$ & $\begin{array}{c}\text { Mean } \\
\text { after } \\
\text { BTX-A }\end{array}$ & $p$-value \\
\hline Mobility & $5.4 \pm 4.9$ & $3.7 \pm 3.7$ & 0.01 & $4.3 \pm 4.3$ & $4.5 \pm 4.3$ & NS & $5.9 \pm 5.1$ & $3.2 \pm 3.3$ & 0.001 \\
\hline $\begin{array}{l}\text { Activities of daily } \\
\text { living }\end{array}$ & $5.7 \pm 4.4$ & $2.9 \pm 3.3$ & 0.000006 & $4.5 \pm 3.7$ & $2.5 \pm 3.1$ & 0.02 & $6.3 \pm 4.7$ & $3.2 \pm 3.4$ & 0.0001 \\
\hline $\begin{array}{l}\text { Emotional } \\
\text { well-being }\end{array}$ & $9.1 \pm 7.3$ & $6.1 \pm 5.9$ & 0.005 & $7.4 \pm 6.9$ & $7.0 \pm 5.7$ & NS & $9.7 \pm 7.3$ & $5.7 \pm 6.0$ & 0.002 \\
\hline Stigma & $9.2 \pm 5.9$ & $5.7 \pm 5.1$ & 0.00008 & $7.6 \pm 6.1$ & $4.4 \pm 5.1$ & 0.04 & $10.0 \pm 5.8$ & $6.4 \pm 5.0$ & 0.0009 \\
\hline Social support & $2.6 \pm 3.0$ & $1.9 \pm 2.4$ & NS & $1.7 \pm 2.1$ & $1.1 \pm 1.2$ & NS & $3.0 \pm 3.3$ & $1.9 \pm 2.7$ & NS \\
\hline Cognition & $4.7 \pm 3.6$ & $3.1 \pm 2.8$ & 0.003 & $4.0 \pm 3.2$ & $3.5 \pm 2.9$ & NS & $4.9 \pm 3.7$ & $2.9 \pm 2.8$ & 0.002 \\
\hline Bodily discomfort & $7.9 \pm 4.9$ & $5.0 \pm 4.1$ & 0.00005 & $7.1 \pm 4.4$ & $4.7 \pm 3.8$ & 0.03 & $8.2 \pm 5.0$ & $5.2 \pm 4.3$ & 0.001 \\
\hline Communication & $2.2 \pm 2.8$ & $1.1 \pm 1.9$ & 0.004 & $1.3 \pm 2.2$ & $0.7 \pm 1.2$ & NS & $2.7 \pm 3.0$ & $1.4 \pm 2.1$ & 0.01 \\
\hline Total & $47.0 \pm 30.9$ & $28.6 \pm 23.7$ & 0.00003 & $38.0 \pm 26.0$ & $25.5 \pm 20.2$ & 0.04 & $50.9 \pm 32.1$ & $30.3 \pm 25.4$ & 0.0003 \\
\hline
\end{tabular}

NS- non-significant

HFS-7, HFS-36) $[3,27,30]$. In a validation study of the HFS-30 questionnaire [30], similarly high correlation coefficients were noted between the severity of HFS symptoms and the scores of some subscales, i.e. activity of daily living $(r=0.51)$, mobility $(r=0.43)$ and stigma $(r=0.43)$. The weakest correlation (similarly to the current study) was found between severity of HFS symptoms and the social support subscale $(r=0.10)$. Our study showed for the first time that the severity of HFS symptoms, measured with the two above-mentioned scales, was an independent risk factor of worse quality of life among patients with HFS. Similar results have been published documenting the impact of symptom severity on worsening of the quality of life in patients with other movement disorders, such as Parkinson disease $[10,11,15]$, essential tremor [21], multisystem atrophy [23], Gilles de la Tourette syndrome [24] and focal dystonia [18,31], although some reports did not confirm that finding [17].

The association between self-evaluated quality of life in HFS and the severity of accompanying symptoms or depression has not been studied before. The current study shows for the first time that the large number of signs accompanying HFS significantly worsens the quality of life, similarly to the greater severity of depressive symptoms. Some HFS-accompanying signs, such as facial pain or discomfort and trismus, significantly impair the quality of life assessed with HFS-36 in almost

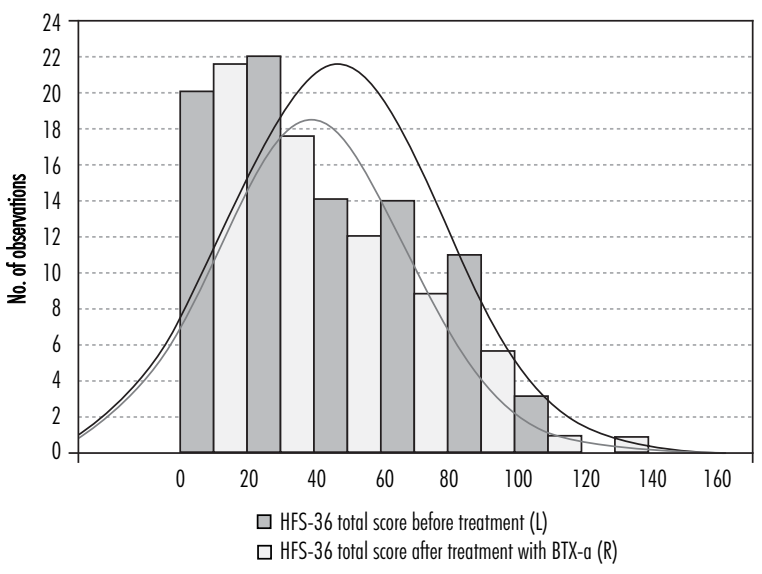

Fig. 2. The total HFS-36 score before and after botulinum toxin (BTX-A) injection

all subscales, while other accompanying signs, such as visual disturbances, photophobia or auditory disturbances, affect particular subscales only, bodily discomfort and communication in particular. Only a few HFSaccompanying signs (dysarthria, sialorrhoea, lacrimation, conjunctival irritation) did not affect the quality of life assessed by patients themselves, which is probably due to their low severity. Similar results in regard of pain as a factor affecting the quality of life in patients with cervical dystonia were published by Müller et al. [16].

The current study also shows for the first time that greater severity of depressive symptoms is an indepen- 
dent risk factor for worse quality of life. The impact of depression and anxiety on the worsening of quality of life has been documented many times in patients with Parkinson disease in various populations, including Portuguese [11], Russian [15], Chinese [12], WestEuropean [9], American [13], as well as Polish populations [8]. The strongest risk factor for worse quality of life in Parkinson disease is depression, regardless of the time of its occurrence: before the occurrence of motor symptoms of Parkinson disease [14], in early [12] or advanced stage of the disease $[8-11,13,15]$. Similarly, a significant impact of depression or anxiety on worsening quality of life was found among patients with cervical dystonia $[17,31]$, progressive supranuclear palsy [22], multisystem atrophy [23], and essential tremor [21], as well as in other, less common movement disorders $[24,25]$.

Depression was diagnosed in $20 \%$ of the patients in this study. The only study published so far on the prevalence of depression in HFS reported its presence in $16.7 \%$ of 90 patients, according to the DSM-IV criteria [5]. The prevalence of depression reported in our study is within the range of depression prevalence in neurological out-patient clinics in Great Britain and the United States (15-30\%) $[5,32,33]$. Somewhat higher prevalence of depression (30-47\%) was reported in focal dystonia, considered as the movement disorder most similar to HFS $[16,17,19]$.

We did not find any influence of age or disease duration on the quality of life scores in our patients. Similar observations regarding duration of HFS and blepharospasm were reported by Hall et al. [7]. The impact of age on the quality of life scores in HFS patients has not been analysed before, but similar analyses have been performed in patients with other movement disorders; some of them showed no such association $[8,22,23]$, while others confirmed it $[15,21,24]$. The literature contains contradictory reports that confirm $[8,22,31]$ or deny [9] the impact of disease duration on the quality of life.

In the present study, treatment with BTX-A significantly improved both the global HFS-36 score and the results of all subscales, except for the social support subscale. This is in agreement with previous studies by Tan et al. [30], who used HFS-30, and Huang et al. [27], who used the HFS-36 questionnaire. Previous studies showed that treatment with BTX-A in patients with HFS led to a marked improvement of the global assessment of quality of life with the visual-analogue scale, included in the quality of life questionnaires [2,35]. Dif- ferent results of the direct influence of BTX-A treatment on the quality of life were reported in patients with focal dystonia. Müller et al. found no change in mean SF-36 score in patients with dystonia who were assessed within several weeks after BTX-A injection in comparison to the same assessment before treatment. There are some observations, however, that document significant improvement of the quality of life after long-term treatment with BTX-A $[17,18,31,34]$.

\section{Conclusions}

1. Independent risk factors of worse quality of life in HFS patients include greater severity of HFS symptoms, greater severity of depressive symptoms, and the occurrence of trismus. The quality of life does not depend, however, on age, sex, or duration of the disease.

2. Treatment with BTX-A improves quality of life in HFS patients due to the reduction of typical motor symptoms and accompanying signs. The quality of life improvement is greater in patients with a greater number of accompanying signs.

\section{Disclosure}

Authors report no conflict of interest.

\section{References}

1. Heuser K., Kerty E., Eide P.K., et al. Microvascular decompression for hemifacial spasm: postoperative neurologic followup and evaluation of life quality. Eur J Neurol 2007; 14: 335-340.

2. Reimer J., Gilg K., Karow A., et al. Heath-related quality of life in blepharospasm or hemifacial spasm. Acta Neurol Scand 2005; 111: 64-70.

3. Tan E.K., Fook-Chong S., Lum S.Y., et al. Validation of a short disease specific quality of life scale for hemifacial spasm: correlation with SF 36. J Neurol Neurosurg Psychiatry 2005; 76: 1707-1710.

4. Tan E.K., Hameed S., Fook-Chong S., et al. Treatment outcomes correlates with knowledge of disease in hemifacial spasm. Clin Neurol Neurosurg 2008; 110: 813-817.

5. Tan E.K., Lum S.Y., Fook-Chong S., et al. Behind the facial twitch: depressive symptoms in hemifacial spasm. Parkinsonism Relat Disord 2005; 11: 241-245.

6. Tan E.K., Fook-Chong S., Lum S.Y. Case-control study of anxiety symptoms in hemifacial spasm. Mov Disord 2006; 21 : 2145-2149.

7. Hall T.A., McGwin G. Jr, Searcey K., et al. Health-related quality of life and psychosocial characteristics of patients with benign essential blepharospasm. Arch Ophtalmol 2006; 124: 116-119. 
8. Zach M., Friedman A., Sławek J., et al. Quality of life in Polish patients with long-lasting Parkinson's disease. Mov Disord 2004; 19: 667-672.

9. Schrag A. Quality of life and depression in Parkinson's disease. J Neurol Sci 2006; 248: 151-157.

10. Forsaa E.B., Larsen J.P., Wentzel-Larsen T., et al. Predictors and course of health-related quality of life in Parkinson's disease. Mov Disord 2008; 23: 1420-1427.

11. Quelhas R., Costa M. Anxiety, depression, and quality of life in Parkinson's disease. J Neuropsychiatry Clin Neurosci 2009; 21: 413-419

12. Qin Z., Zhang L., Sun F., et al. Depressive symptoms impacting on health-related quality of life in early Parkinson's disease: results from Chinese L-dopa exposed cohort. Clin Neurol Neurosurg 2009; 111: 733-737.

13. Jones C.A., Pohar S.L., Patten S.B. Major depression and health-related quality of life in Parkinson's disease. Gen Hosp Psychiatry 2009; 31: 334-340.

14. Klepac N., Hajnsek S., Trkulja V. Impact of pre-morbid depression on health-related quality of life in non-demented Parkinson's disease patients. Parkinsonism Relat Disord 2010; 16: 21-27.

15. Winter Y., von Campenhausen S., Popov G., et al. Social and clinical determinants of quality of life in Parkinson's disease in a Russian cohort study. Parkinsonism Relat Disord 2010; 16: 243-248

16. Müller J., Kemmler G., Wissel J., et al.; Austrian Botulinum Toxin and Dystonia Study Group. The impact of blepharospasm and cervical dystonia on health-related quality of life and depression. J Neurol 2002; 249: 842-846.

17. Slawek J., Friedman A., Potulska A., et al. Factors affecting the health-related quality of life of patients with cervical dystonia and the impact of botulinum toxin type A injections. Funct Neurol 2007; 22: 95-100.

18. Skogseid I.M., Malt U.F., Røislien J., et al. Determinants and status of quality of life after long-term botulinum toxin therapy for cervical dystonia. Eur J Neurol 2007; 14: 1129-1137.

19. Lewis L., Butler A., Jahanshahi M. Depression in focal, segmental and generalized dystonia. $J$ Neurol 2008; 255: 1750-1755.

20. Pekmezovic T., Svetel M., Ivanovic N., et al. Quality of life in patients with focal dystonia. Clin Neurol Neurosurg 2009; 111: 161-164

21. Woods S.P., Scott J.C., Fields J.A., et al. Executive dysfunction and neuropsychiatric symptoms predict lower health status in essential tremor. Cogn Behav Neurol 2008; 21: 28-33.

22. Schrag A., Selai C., Davis J., et al. Health-related quality of life in patients with progressive supranuclear palsy. Mov Disord 2003; 18: $1464-1469$.

23. Schrag A., Geser F., Stampfer-Kountchev M., et al.; European MSA-Study Group. Health-related quality of life in multiple system atrophy. Mov Disord 2006; 21: 809-815.

24. Müller-Vahl K., Dodel I., Müller N., et al. Health-related quality of life in patients with Gilles de la Tourette's syndrome. Mor Disord 2010; 25: 309-314.

25. Gerschlager W., Katzenschlager R., Schrag A., et al. Quality of life in patients with orthostatic tremor. $J$ Neurol 2003; 250: $212-215$
26. Tan E.K., Jankovic J. Bilateral hemifacial spasm: a report of 5 cases and a literature review. Mov Disord 1999; 14: 345-349.

27. Huang Y.C., Fan J.Y., Ro L.S., et al. Validation of a Chinese version of disease specific quality of life scale (HFS-36) for hemifacial spasm in Tajwan. Health Qual Life Outcomes 2009; 7: 104 .

28. Beck A.T., Ward C.H., Mendelson M., et al. An inventory for measuring depression. Arch Gen Psychiatry 1961; 4: 561-571.

29. Kendall P.C., Hollon S.D., Beck A.T., et al. Issues and recommendations regarding use of the Beck depression inventory. Cogn Ther Res 1987; 11: 289-299.

30. Tan E.K., Fook-Chong S., Lum S.Y., et al. Botulinum toxin improves quality of life in hemifacial spasm: validation of a questionnaire (HFS-30). J Neurol Sci 2004; 219: 151-155.

31. Ben-Shlomo Y., Camfield L., Warner T; ESDE collaborative group. What are the determinants of quality of life in people with cervical dystonia? J Neurol Neurosurg Psychiatry 2002; 72: 608-614.

32. Carson A.J., Postma K., Stone J., et al. The outcome of depressive disorders in neurology patients: a prospective cohort study. J Neurol Neurosurg Psychiatry 2003; 74: 893-896.

33. Williams L.S., Jones W.J., Shen J., et al. Prevalence and impact of depression and pain in neurology outpatients. $J$ Neurol Neurosurg Psychiatry 2003; 74: 1587-1589.

34. Hilker R., Schischniaschvili M., Ghaemi M., et al. Health related quality of life is improved by botulinum neurotoxin type A in long term treated patients with focal dystonia. J Neurol Neurosurg Psychiatry 2001; 71: 193-199.

35. Schnider P., Birner P., Moraru E., et al. Long-term treatment with botulinum toxin: dosage treatment schedules and costs. Wien Klein Wochenschr 1999; 11: 59-65. 